\title{
The Dollar's Effective Exchange Rate: Assessing the Impact of Alternative Weighting Schemes
}

\author{
Mack Ott
}

$\mathbf{M}$ tain that a multilateral weighted exchange rate is more useful than any single bilateral exchange rate in assessing the value or changes in the value of the dollar." A multilateral or effective exchange rate (EER), which comprises many exchange rates, avcids mistaken generalizations that can result from changes peculiar to a single currency. Moreover, the EER reflects thirdcountry impacts on the dollar's exchange value, which are excluded in a bilateral exchange rate.

The construction of an EER entails two analytic problems. First, which currencies should be included? Second, how should the included currencies be weighted? 'These issues appear to be inextricably related, so that the correct choice for one issue would seem always to be conditional on the correct choice for the other. Yet, some insights about the relative importance of the choice of weights can be obtained by examining the effects of changing the weights for a given set of exchange rates.

This article examines the weighting issue using the Federal Reserve Board's Trade-Weighted Exchange Rate (TWEX), In particular, EERs constructed with trade weights, capital-flow weights and equal ("naive") weights are compared in terms of their explanatory

Mack Ott is a senior economist at the Federal Reserve Bank of St. Louis. dames C. Polefti provided research assistance.

'See Black (1976), Hooper and Morton (1978), Maciejewski (1983), Dution and Grennes (1985), Belongia (1986), Cox (1986) and Rosensweig (1986) power and out-of-sample forecasts in a trade equation.

\section{THE USE OF EFFECTIVE EXCHANGE RATES}

The usefuness of an EER can be illustrated by asking whether the dollar has strengthened or weakened during some interval. ${ }^{2}$ As chart 1 shows, the value of the dollar has appreciated against some curencies and depreciated against others since 1973. For exam ple, the dollar has appreciated against the Canadian dollar and sterling, is about the same in 1986 as it was in 1973 against the $\mathrm{DM}$, and has depreciated vis-à-vis the yen and Swiss franc. Within this 13-year span, most currencies have exhibited similar relative pat terns against the dollar, peaking in 1980 and bottoming out in 1985. In contrast, the yer, Canadian dollar, Swiss franc and sterling each have had substantial departures from the common patterns. The Swiss currency has been notable for its consistently strong dollar value - - the dollar buying roughly half the number Swiss francs in 1986 that it could in 1973.

Moreover, as chart 2 shows, adjusting these bilateral exchange rates for different rates of inflation between the United States and the respective countries yield

${ }^{2}$ For expository purposes, therefore, we will use levels of the constituent exchange rates in illustrating and explaining EERs. For many analytical appications, levels of the EER are less useful that theit changes; consequently, the remainder of the aticle will focus on changes in the variously defined EERs. 


\section{Chart 1}

\section{Nominal Dollar Exchange Rates for G-7 Countries and Switzerland}

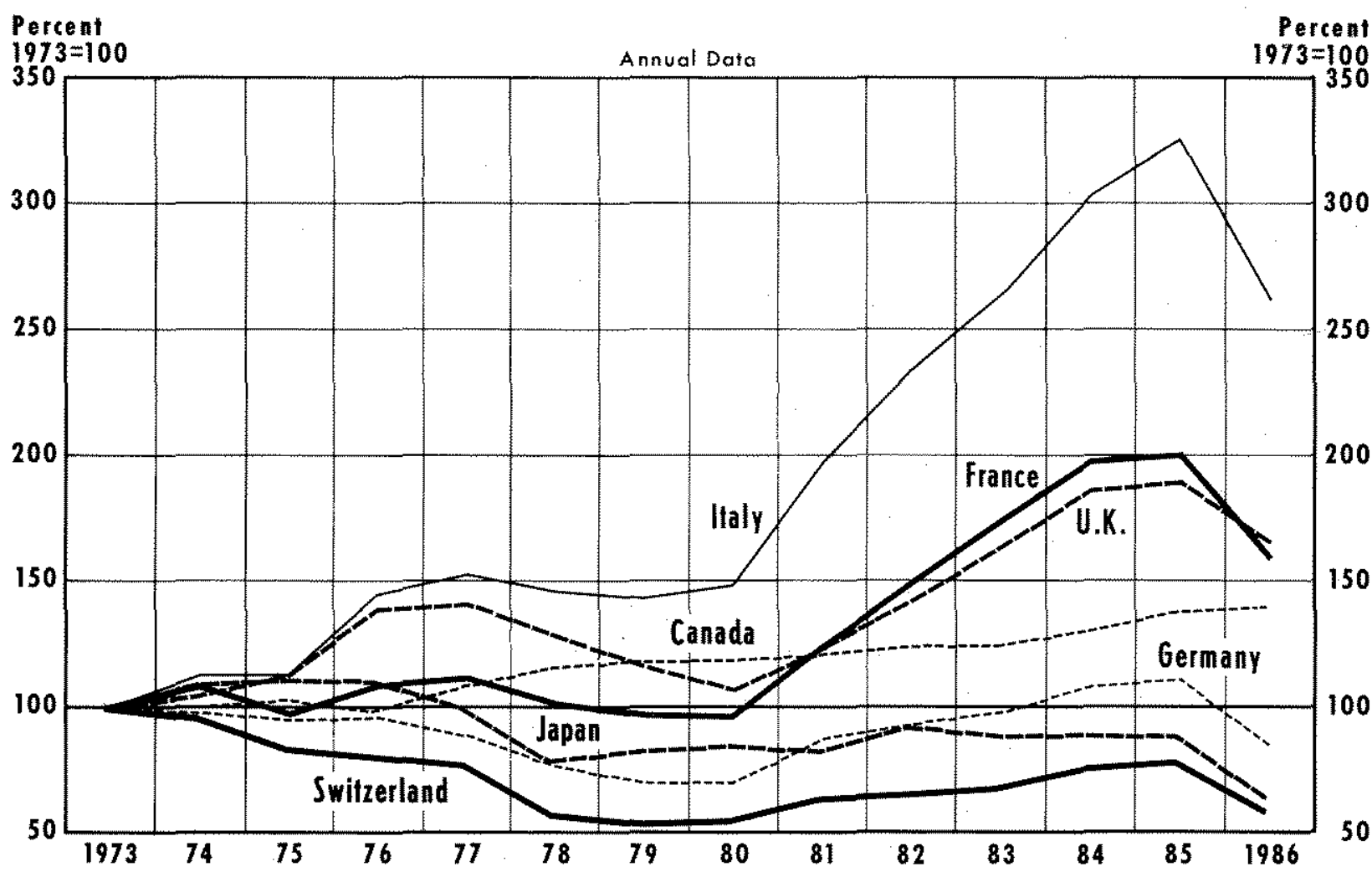

similar patterns. The dollar's real exchange rates against these currencies ladjusted by consumer price indexes) also demonstrate disparate assessments of the change in the dollar's value during this period.

Still, most analysts believe that the dollar appreciated during 1973-86. Such an assessment must be based on some type of weighting scheme - that is, an average of the currencies' exchange rates is implicitly evaluated. The use of EERs is simply an explicit formalization of this principle.

\section{CONSTRUCTING AN EER: SOME GENERAL ISSUES}

In order to construct an EER, several questions must be answered: Which currencies should be included? What measure of international commerce should be used to weight these currencies? ${ }^{3}$ Should the weights be based on bilateral or multilateral ex change? Should the weights be arithmetic or geomet ric? What time period should be used for the weights? It has been commonly argued that the answers to each of these questions depends upon the purpose of the analysis - that is, the use to which the EER will be applied.

\section{Which Currencies?}

This choice generally has been governed by a compromise between completeness of the set of trading

sWith the exception of the IMF's Muttiateral Effective Exchange Rate (MEAM), which has weights generated from the solution of a trade model, all major EERs are trade-weighted.

“See Hooper and Morton (1978), Belongia (1986) and Rosensweig (1986). 
Chart 2

\section{Real Dollar Exchange Rates for G-7 Countries and Switzerland}

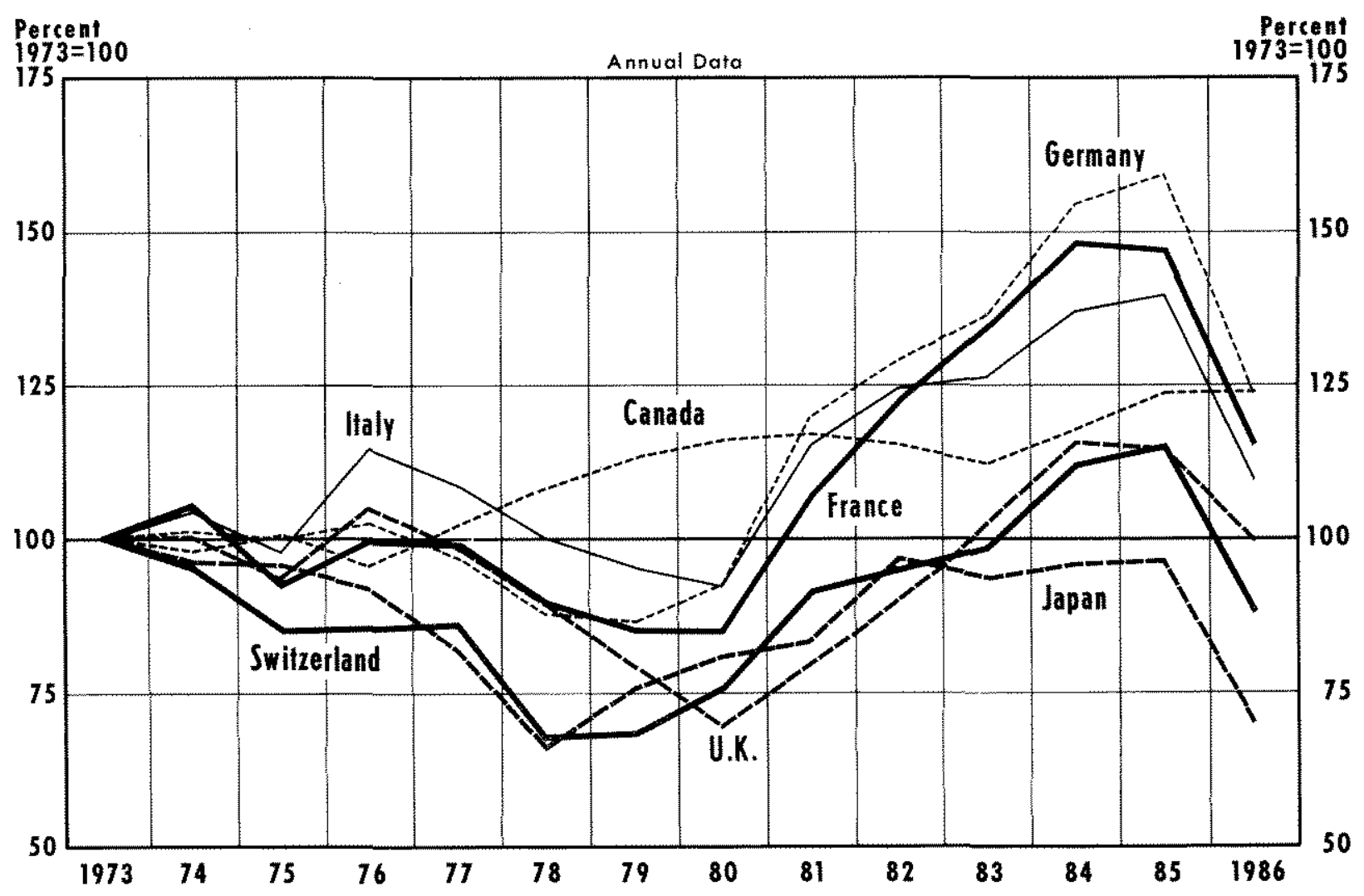

partners and data availability. Most indexes use the principal industrial economies' currencies. The International Monetary fund's (IMF's) Multilateral Effective Exchange Rate (MERM) covers 21 countries, Morgan Guaranty Trust of New York uses 15 industrial coun tries' currencies and the Federal Reserve Board's TWEX, the best known example of such an index, is based on the Group of 10 countries plus Switzerland. ${ }^{5}$ The currencies in TWEX are used both because of the availability of data and because these countries account for most intemational trading activity. Moreover, the 10 U.S. trading pantners in the $\mathrm{G}-10$ countries plus Switzertand also account for most U.S. foreign trade. For example, in 1973, these countries accounted for 60.1 percent of U.S. exports plus imports; including the United States, these 11 countries accounted for

5 See Belongia (1986) for a fuller discussion of these indexes and their characteristics. In contrast, Cox (1986) has recently formulated an index covering all 131 of the U.S. trading partners.
67.2 percent of world exports plus imports. In 1983 , these proportions fell to 52.5 and 53.8 percent, respectively; then rose to 58.5 and 62.4 percent in 1985 .

\section{What Measure of Commerce?}

Except for the IMF's MERM, all existing EERs are weighted by some measure of traded goods and semvices, the sum of exports plus imports. Yet, either capital flows or trade flows - that is, either side of the balance of payments statistics - would seem to be reasonable bases for weighting exchange zates. As Hooper and Morton observe,

The total supply of and demand for dollars on foreign exchange markets derive from U.S. demands for for eign goods and foreign currency-denominated finan. cial assets and foreign demands for U.S. goods and dollar denominated financial assets. . . An excess sup-

\footnotetext{
${ }^{6}$ See Dutton and Grennes (1985).
} 
ply of dollars resulting from a decline in demand for U.S. goods or dollar denominated assets would tend to cause a decline in the foreign currency price of the dollar?

Thus, using capital flows, measured as the sum of domestic investment flows abroad and foreign investment flows in the home country, provides an altemative approach for weighting each currency's importance. Consider, briefly, the arguments in favor of each.

Trade flow weights Trade flow weights for the EER measure the direct impact on income through net exports) of the foreign sector. Thus, a country whose trade share is large is one whose economy's impact on U.S. markets is large, while a country with a smaller trade share has less impact. The larger this share, the greater is the competitive importance of that country's producers for U.S. producers. Hence, the EER should also reflect these relative rankings of U.S. competitors' currencies.

Capital flow weights Capital flow weights for the EER scale the currencies by the magnitude of the financial flows between the respective countries. The currencies of countries with larger investment and portfolio flows are more important competitors for the dollar in international transactions than are currencies of countries with smaller investment and portfolio activity. Unlike trade weights, which emphasize an income approach to exchange rate determination, capital flow weights emphasize a financial approach to the dollar's valuation. An EE using capital flow weights will reflect these financial market consider+

'Hooper and Morton (1978), p. 784; italics added.

${ }^{8}$ While capital flow weights emphasize the financial side of the batance of payments flows, they are not completely consistent with the modern asset markel view of exchange rate determination which emphasizes stocks rather than flows; see Dornbusch (1976), Frenkel $(1976,1981)$, and Mussa $(1979,1982,1984)$. As summarized by Mussa (1979, p. 38):

The asset market approach views the exchange rate as being determined by essentialty the same forces that determine the prices of other assets that are traded in organized asset markets, such as the stock sharkets and the commodity exchanges. In such markets, prices are determined not by the balancing of fow demands and flow supples, but rather by the prices at which the market as a whole is prepared to hold the total outstanding stocks of the assets in question. Since the assets in question are durable, the currently determined price of an asset is tiahtly linked to the market's expectation of the future price of that asset. (italics added)

The measures of capital flows used in constructing the capital weights are the annual net increment in national asset portolios by financial asset class. To the extent that the relative national asset holdings (stocks) of these financial assets do not change, the relative net flows would be proportional to the unobserved stocks. ations and the relative importance of the non-U.S. currencies in intemational finance.

\section{Multilateral or Bilateral Weights?}

Under multilateral weighting, each country receives a weight equal to its proportion of total trade or capital flows. Under bilateral weighting, each county receives a weight equal to its proportion of the flows to and from the United States. Bilateral flows seem closer to the notion of measuring the importance of individual U.S. trading partners to U.S, economic activity; however, they omit third-party effects. For example, if the DM-price of antos rises, other things the same, the German share of U.S. auto imports would fall, and the Japanese, Italian and Swedish share of U.S. imports would increase. Analogously, considering financial assets, a multilateral weighting scheme is preferable because it includes these multicountry financial market implications."

\section{Base Period?}

This choice may depend on the period of the analy sis. If the relative size of trade or capital flows of the included countries are changing, it would seem that the base period should be chosen so that the weights characterize the structure of commerce or investment throughout the period of analysis. If the structure shifted, the weights from an earlier period conceivably would no longer reflect the current trade or capital relations. ${ }^{10}$

\section{Arithmetic or Geometric?}

The form of the index carries implications for the comparative importance of absolute vs. percentage changes. Most indexes, in particular the 'TWEX, are weighted geometrically, so that proportional changes are emphasized."

9See Black (1976) and Hooper and Morton (1978). Hooper and Morton also note that the bilateral construction assigns Canada a 20 percent weight in the EER, which is probably distorted by the crossborder trade in partially completed automobile assemblies. Recently, much attention has been focused on the dispute between adherents of bilateral vs. multilateral trade flows; see Belongia (1986), Cox (1986) and Rosensweig (1986).

${ }^{10}$ Based on this possibility, Cox (1986) uses a moving-average weighting scheme. This makes evaluation of the dollat problematic since changes in its value may result from changes in weights, not from changes in exchange values.

"See Board of Governors of the Federal Reserve System (1978) and Belongia (1986). Among widely used EERs, only the HMF's SDR is arithmetically weighted. 


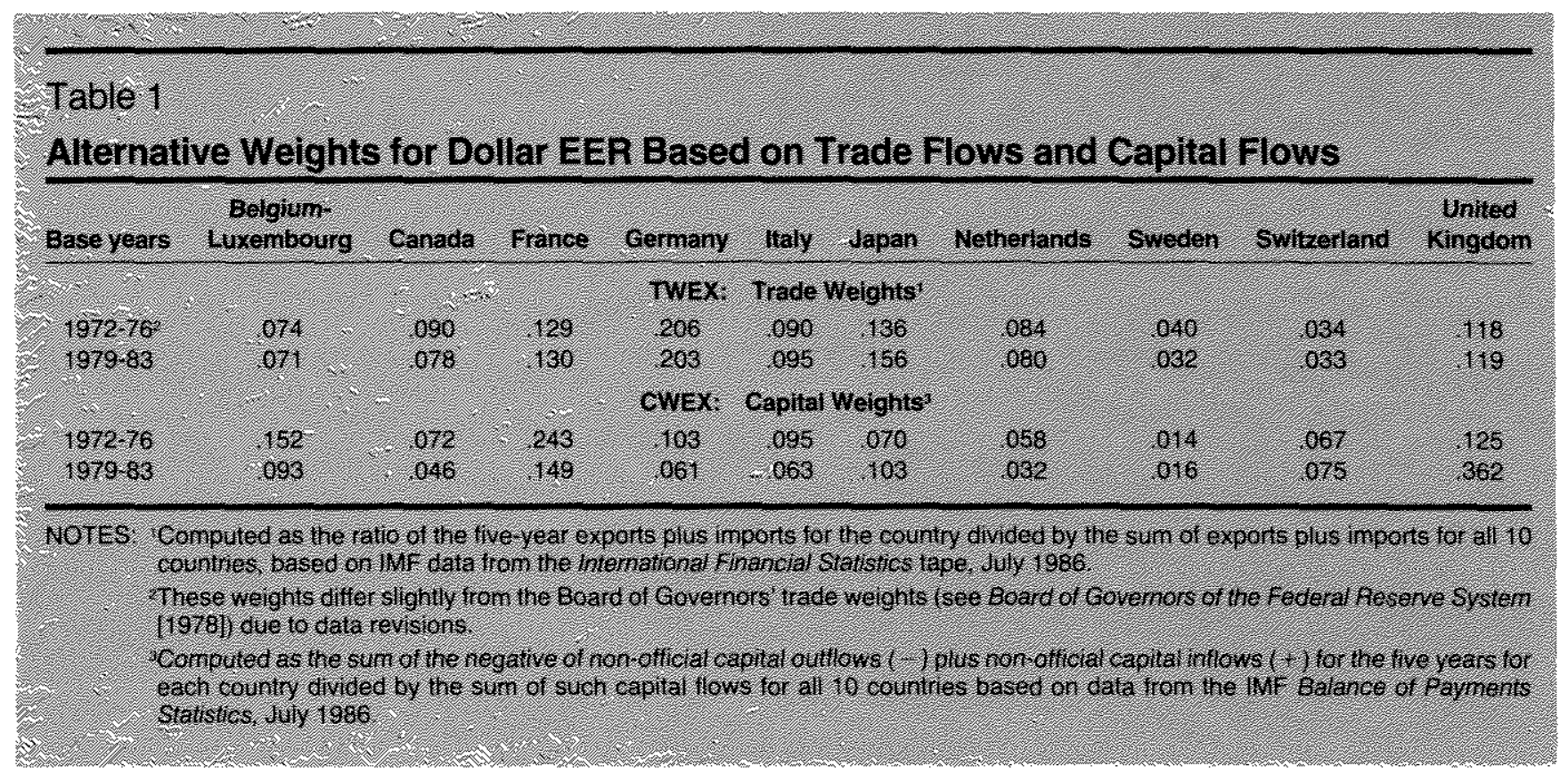

\section{COMPUTATION OF TRADE AND CAPITAL WEIGHTS FOP EER INDEXES}

As noted above, the weighting schemes generally applied in EERs are derived from data on trade flows, not capital flows. Yet, for the reasons offered above, capital flows offer a potentially useful alternative for weighting the exchange rates in an EER.

The construction of the Capital weighted Exchange Rate (CWEX) essentially parallels that of the TWEX. Since IWEX is familiar to most readers, we briefly review its construction, then examine that of CWEX. Following this, we show how each index is put into real terms; this deflation results in the priced-adjusted indexes, RTWEX and RCWEX.

\section{TIVEX}

This index is constructed by computing the trade flows (imports plus exports) of each of the non-U.S. $G-10$ countries as a percent of the total for all of these countries. These weights are computed as the average for a five-year base period; two periods were used, $1972-76$ and $1979-83$. TWEX is then computed as the product of these weights multiplied by the natural log (n) of the respective exchange rates, indexed to March 1973. Thus,

\footnotetext{
$10 \mathrm{w}$

(1) $\operatorname{TWEX}_{\mathrm{t}}=100 \pi \mathrm{R}_{\mathrm{it}}$ $i=1$
}

$$
=100 \exp \sum_{i=1}^{10} w_{i} \ln R_{i}
$$

where the weight for country $i$ is

$$
w_{i} \equiv\left(\text { Imports }_{i}+\text { Exports }_{i} y / \sum_{j=1}^{10}\left(\text { Imports }_{i}+\text { Exports }_{i}\right),\right.
$$

and

$\mathrm{P}_{\mathrm{it}} \equiv$ price in U.S. cents of currency i in March 1973

The alternative forms of the exchange rate index, equation 1, are shown to emphasize that TWEX is a geometric rather than an arithmetic average of the constituent exchange rates. Also, note that TWEX is specified in average foreign currency units per dollat and is indexed to its value at the beginning of the floating-rate period, March 1973. Thus, a rise in TWEX means the dollar's value is increasing; and values over 100 mean that its weighted foreign currency value is greater than it was in March 1973.

The weights for the two base periods, $1972-76$ and $1979-83$, are displayed in table 1 .

\section{CWEN}

This index is constructed by computing the nonofficial ne: capital flows (imports plus exports) of each of the non-U.S. G-10 countries as a percent of the total for all of these countries. 'These capital flows include direct investment, portfolio investment, other long- 
and short-term capital flows of deposit money banks and nonbank sectors as reported in the International Monetary Fund's Balance of Payments Statistics; a detatled breakdown of the included items appears in the appendix. ${ }^{12}$

Only non-official capital flows were used. This restriction is based on the assumption that private agents will buy and sell assets based on rationally formed forecasts of relative asset values and anticipated changes in those values in order to maximize their wealth. Official flows, in contrast, may be driven by attempts to change values or offset market anticipations. To the extent that these interventionist policies are successful, they will be reflected in non-official flows; otherwise, they are merely noise. ${ }^{13}$

Thus, the index is defined parallel to TWEX as

(2) $\mathrm{CWEX}_{1}=100 \exp \sum_{i=1}^{10} x_{i} \log _{\mathrm{e}} \mathrm{R}_{\mathrm{if}}$

where the weight for country i is

$$
\begin{aligned}
& \left.x_{i}=\text { (Capital Outflows } s_{i}+\text { Capital Inflows } s_{i}\right) \\
& 10 \\
& \left.\sum \text { (Capital Outfows }+ \text { Capital Inflows } s_{j}\right)
\end{aligned}
$$

The weights for CWEX for the two base periods are also displayed in table $1^{14}$

\section{Feal EERs}

For many analytic purposes, price adjusted EERs, here RTWEX and RCWEX, are more useful than nominal EERs. These real indexes, in principle, are constructed by weighting the real (price-deflated) $e^{-x}$ -

\footnotetext{
${ }^{12}$ One reservation about the capital weighting scheme is that it adds net capital outflows plus net capital intlows while trade weights are, in principle, based on gross exports plus gross imports. Yet, the capital flows used in constructing the CWEX EERs are the sum of narrowly specified asset categories; hence, while inflows and outflows within any category (e.g., Horeign holdings of corporate equities) are netted out, there is no cancelation across assef categories (e.g., toreign holdings of corporate equities and toreign holdings of public sector bonds)

"See Batten and Ot (1984) for a general discussion of both the motivation for and the limitations on the efficacy of central bank foreign exchange intervention.

${ }_{14}$ An alternative version of the capital weights was computed because Switzerland reported no data on direct investment overseas investment by the Swiss and foreign investment in Switzerland. Since direct investment constitutes a substantial portion of the capital flows for the other countries, this would be likely to bias downward the weight for the Swiss franc. To compensate for this omission, a capital-weighted exchange rate index with net errors and omissions (CWEXO) was comouted in the same manner as TWEX and CWEX; see appendix. The results of its comparative performance in the tests below, however: were indistinguishable from those reported and are omitted.
}

change rates; however, this is equivalent to dividing the nominal index by the ratio of a weighted index of foreign CPIs to the U.S. CPI. Thus, the real TWEX (RTWEX) is obtained as

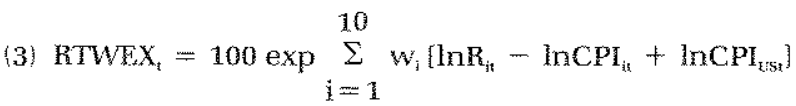

$$
\begin{aligned}
& =100 \exp \left[\sum_{i=1}^{10} w_{i} \ln R_{: 1}-\sum_{i=1}^{10} w_{i}\left(\operatorname{lnCPl_{it}}-\operatorname{lnCPl_{tSi})}\right]\right.
\end{aligned}
$$

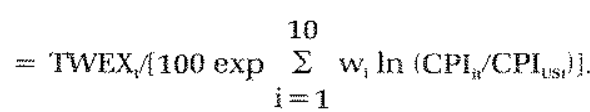

$$
\begin{aligned}
& =\mathrm{TWEX}_{1} / \mathrm{WCPI}_{\text {. }}
\end{aligned}
$$

The real CWEX ( $\mathrm{RCWEX}$ ) is obtained analogously as

$$
\text { (4) } \begin{aligned}
\operatorname{RCWEX}_{\mathrm{i}} & =\mathrm{CWEX}_{\mathrm{r}} / 100 \mathrm{exp} \sum_{i=1}^{10} \mathrm{x}_{\mathrm{i}} \ln \left(\mathrm{CPI}_{\mathrm{if}} / \mathrm{CPI}_{\mathrm{i}, s \mathrm{~s}}\right) \\
& =\mathrm{CWEX}_{\mathrm{i}} / \mathrm{CWCPI}_{\mathrm{i}} .
\end{aligned}
$$

\section{COMPARISONS OF TIL ALTERNATVE EERS}

In order to determine whether different weighting schemes yield different results, empirical assessments were made of their comparative usefuness. These empirical analyses focused on changes, rather than levels, in the alternative EERs.

First, correlation coefficients were computed for the change in the natural logarithm (delta in of the EERs, both nominal and real. Second, the real EERs were each included as an explanatory variable in a trade equation with changes in U.S. agricultural exports as the dependert variable." These estimates and their out-of-sample forecasts provide measures of the relative explanatory power of the different weighting schemes. In each of these empirical exercises, a "naive" EER, in which each currency received equal weight, was also included as a benchmark (or null hypothesis to see whether the theoretically based weights yielded superior results.

\section{Correlation among the ERRs}

The correlations among these five exchange rate series, both nominal and real (CPI-deflated), are reported in table 2 , and the results are striking. The delta In of these alternative EERs' time series of changes are nearly perfectly correlated: the correlation coeficients

\footnotetext{
15The choice of model was made to facilitate further comparisons with the related work by Belongia (1986) on alternative exchange rate measures.
} 


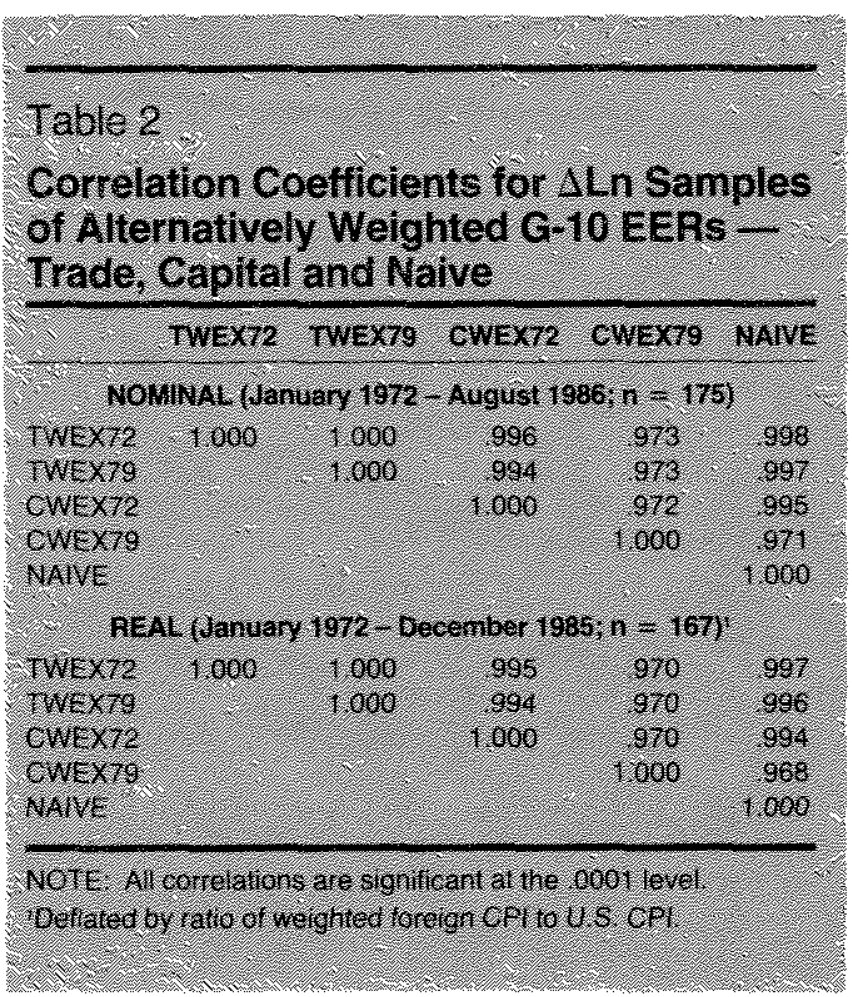

between the five EERs vary from 968 to 1.000 (rounded to 3 significant digits); this relationship holds for both nominal and real changes specifications. While the extremely high correlations both among the exRs and among the REERs may seem to imply that they will be virtually identical in any empirical application, this generally is not convect. For example, Belongia found that, although different heERs were highly correlated, they generated different regression coefficients and highly divergent out-of-sample forecasts. Consequently, the regression and forecast comparisons are included here in order to determine whether or not these REERs perform identically.

\section{Regression and Forecast Results for the EERs}

In Belongia (1986), an equation explaining U.S. agriculitural exports was estimated utilizing, in turn, five different REERs: the Federal Reserve Board's TWEX the MF's MERM and SDR, Morgan Guaranty's EER, and the US. Department of Agriculture's AG-Export weighted EER. These estimates afford a comparison of the explanatory power and out-of-sample forecasts of the five REERs. Belongia found that these real exchange rates had substantially different regression and out-of-sample properties, even though the correlation coeficients among them ranged from 853 to 983. Consequently, estimating some trade equation, such as that used by Belongia, provides one direct way to determine determining whether REERs that vary only in their weighting schemes also produce disparate regression and outmof-sample forecast results.

Since this article focuses on the usefulness of the percentage change on delta in EER series, a delta ln version of Belongia's (1986) model was used to compare the results of the alternative EERs. The purpose of this test was not to determine the best trade equation or test the validity of the specific equation estimated. Rather, the purpose was simply to see how differently each EER series performed using a typical trade equation from the trade literature.

The estimated equation is

$$
\begin{aligned}
& \text { (5) } \Delta \ln X_{1}=a_{i}+\sum_{i=0}^{1} a_{1 i} \Delta \operatorname{LnFGN} P_{2-i} \\
& \left.+\sum_{j=1}^{2} a_{2 j} \text { An (USAGP/USCPy }\right)_{t-i} \\
& +\sum_{k=1}^{3} a_{3 k} \Delta \ln \operatorname{REER}_{t+k}+\varepsilon_{1}
\end{aligned}
$$

where,

$$
\begin{aligned}
& \mathrm{X}_{4}=\text { real exports of U.S farm commodities } \\
& \text { FGNP = foreign real GNP }{ }^{\text {th }} \\
& \text { USAGP = index of U.S. farm prices, } \\
& \text { USCPI }=\text { U.S. CPI } \\
& \text { RERR = real TWEX72, WWEX79, CWEX72, CWEX79, } \\
& \text { NAIVE and } \\
& \varepsilon=\text { random error term. }
\end{aligned}
$$

The results of estimating this equation on quarterly data over $1 / 1973-$ rV/1981 are reported in table 3; statistics for out-of-sample forecasts over $1 / 1982-1 / 1985$ are reported in table 4.

The summed coefficients are displayed for FGNP and USAGP/USCPI and the individual coefficients for the $\operatorname{Aln}$ REERs. These coefficients and their significance levels, as reported in table 3 , are very similar across the five specifications for the non-REER variables, as are the $\bar{R}^{2}$ and Durbin-Watson statistics. The latter imply that the residuals do not have significant first-order correlation. The magnitude, signs and $t-$ ratios for the REERs are also similar, although the sums of the REER coefficients differ slightly - the

16This series, obtainable from the Federal Reserve Board is a hybrid of weighted foreign GNPS, containing Mexican and other oifexporting counries' GNPS as well as the (non U.S.) G-10 plus Swizerland industrial countries' GAPs. 


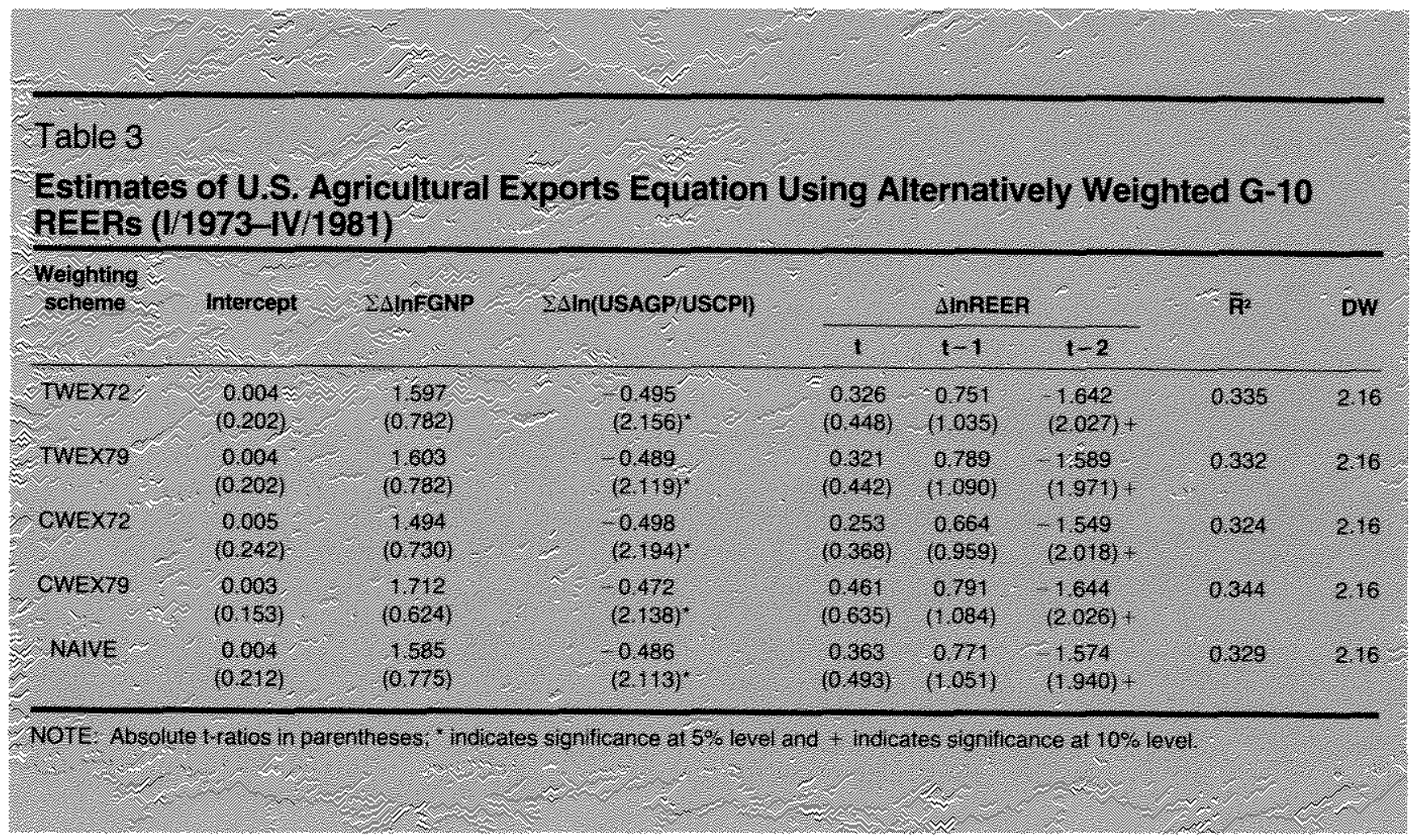

CWEX72 being smaller and CWEX79 larger than the other three, although not significantly so, ${ }^{37}$

The out-of-sample forecast properties of the five estimates of equation 5, differing only in their REERs, are shown in table 4. Error statistics and Theil statistics from the forecast series are displayed. The error statistics - the mean error, the mean absolute error and the root-mean-square ertror (PMSE) - are nearly identical for the five equations. Thus, the accuracy of the forecasts does not vary with the weighting scheme used for the REER. The Theil statistics decompose the forecast errors into three components. ${ }^{\text {s }}$ As shown in these error decompositions, there is no substantive difference in the pattern of the forecast errors.

The close conformity of the regression and forecast results for the variously weighted versions of the $\mathrm{G}-10$

\footnotetext{
${ }^{17}$ Some differences in these sums may reflect scale differences, as the CWEX72 and CWEX79 have weights which differ most from TWEX72; see table 1 .

"Bias measures the proportion of the mean square error (RMSE squared) due to a tendency to estimate too high or too low the level of the forecast. Variance measures the proportion of the MSE due to the variance of predictions differing from the variance of actual levels. The covariance is, essentially, the residual error proportion.
}

REERs contrasts starkly with the divergent results reported for different REERs in Belongia (1986). There are two key differences between Belongia's and those shown here. First, the REERs in this study contain the same currencies; differences between them are limited solely to alternative weighting schemes. In contrast, Belongia used REERs that differed both in their currencies and in their weighting. Second, the analysis here focuses on changes in the In REER; Belongia focused on levels of these data.

\section{CONCLUSOON}

Trade-weighted effective exchange rates are widely used to assess both the value of the dollar as an end in itself and to provide a broad measure for use in analyzing and explaining trade and capital flows. Surprisingly, while questions often arise about which curren" cies to include or how to weight them, alternatives to asymmetrically trade-weighted EERs have seldom been examined.

Several alternative EERs have been examined in this article. An important finding is that the equally weighted naive FER is highly correlated with both the traditional trade-weighted EERs and alternative capital-flow-weighted EERs over the range of consid- 


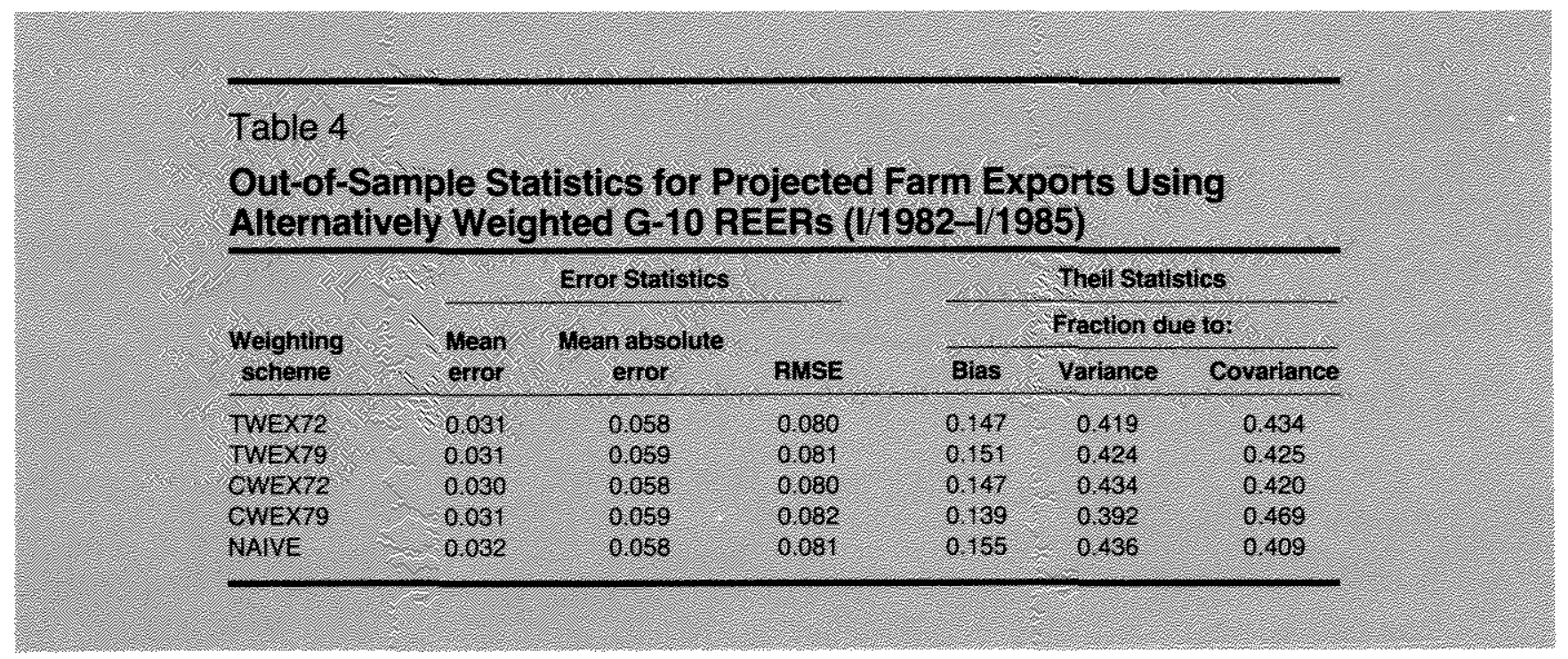

ered weights. Moreover, the explanatory and predictive power of the alternative EERs, including the naive EER, were found to be statistically equivalent in an agriculture export equation. Since these results are for one set of currencies and for one historical period, generalizations must be advanced with care; however, these results suggest that further research - both empirical and theoretical - on the comparative importance of the choice of weighting schemes vs. the choice of currencies to be included in the EER is warranted."

\section{PERERENCES}

Artus, Jacques R., and Rudolf R. Rhoneberg. "A Multilateral Ex* change Rate Model," International Monetary Fund Staff Papers (November 1973), pp. 591-61:.

Batten, Dallas S., and Mack Ott. "What Can Central Banks Do About the Value of the Dollar?" this Review (May 1984), pp. 16-26.

Belongia, Michael T. "Estimating Exchange Effects on Exports: A Cautionary Note," this Review (January 1986), pp. $5-16$.

19|ronicaliy, Irving Fisher (1922, p. 365) first advanced the importance of this question 65 years ago atter arriving at an analogous empirical finding for weighting schemes for price indexes:

Among the consequences of the surprising agreement between the various legitimate methods of calculating index numbers are two which need emphasis here. The first is that all discussion of "different formulat appropriate for different purposes" fals to the ground. The second is that, the supposed differences among formulae once banished, the reat problem of accuracy is shitted to the other features of an index number, - the assortment of the commadities included. their number, and data.

Thus the figures for weights in particular may usually be tenfold of one tenth of the true figures without appreciably disturbing the accuracy of the resutting index number. Henceforth, the effort to improve the accuracy of index numbers must center chiefly on the assortment of the items to be included.
Black, Stanley W. "Multilateral and Bilateral Measures of Effective Exchange Rates in a World Model of Traded Goods," Journal of Political Economy (June 1976), pp. 615-21.

Board of Governors of the Federal Reserve System. "Index of the Weighted-Average Exchange Value of the U.S. Dollar: Revision," Federal Reserve Bulfetin (August 1978), p. 700.

Cox, Michael. "A New Alternative Trade-Weighted Dollar Exchange Rate Index," Federal Reserve Bank of Dallas Economic Review (September 1986), pp. 20-28.

Dornbusch, Rudiger. "Expectations and Exchange Rate Dynamics, "Joumal of Political Economy (December 1976), pp. $1161-$ 76.

Dutton, John, and Thomas Grennes. "The Measurement of Effective Exchange Rates Appropriate for Agricultural Trade," mimeograph, Department of Economics and Business, North Carolina State University (Augusł 1985).

Fisher, Irving. The Making of Index Numbers (Houghton-Mifflin Company, 1922).

Frenkel, Jacob A. "Flexible Exchange Rates, Prices and the Role of 'News': Lessons from the 1970s," Joumal of Poltical Economy (August 1981), pp. 665-705.

Hooper, Peter, and Jolm Morton. "Summary Measures of the Dollar's Foreign Exchange Value," Federal Resenve Bulletin (October 1978), pp. $783-89$

Maciejewski, Edouard B. " "Real' Effective Exchange Rate Indices," International Monetary Fund Staff Papers (September 1983), pp. $491-541$.

Mussa, Michael. "Empirical Regularities in the Behavior of Exchange Rates and Theories of the Foreign Exchange Market," Policies for Employment, Prices and Exchange Rates, in Karl Brunner and Altan Meltzer, eds. Carnegie-Rochester Conference Series on Public Policy, Volume 11 (1979), pp. 9-58.

"A Model of Exchange Rate Dynamics," Journal of Political Economy (February 1982), pp. 72-104.

"The Theory of Exchange Rate Determinations," John F. O. Bitson and Richard C. Monston, eds., Exchange Rate Theory and Practice, University of Chicago Press, 1984.

Rosensweig, Jeffrey A. "A New Dollar Index: Capturing A More Global Perspective," Federal Reserve Bank of Atlanta Economic Review (June/July 1986), pp. 12-22. 


\section{Appendix}

\section{Sources of Data and Specification of Weights}

TWEX: Data are from the July 1986 edition of the International Financial Statistics tape of the IMF. The data utilized are the imports of goods and services plus the exporis of goods and services in billions of U.S. dollars, annual during 1972-76 and 1979-83.

CWEX: Data are from the July 1986 edition of the Balance of Payments Statistics tape of the IMF. The data utilized are:

\section{Line Data Description}

\section{Direct Investment}

Direct Investment Abroad

Foreign Direct Investment at Home

\section{Portfolio Investment}

60

Public Sector Bonds Official Liabilities Other Liabilities

Other Bonds Assets Official Liabilities Other Liabilities

Corporate Equities Assets Official Liabilities

Assets

$-6 A 1 \times 4$

$6 \mathrm{~T} 1 \mathrm{X}_{4}$

$6 \mathrm{Q} 1 \mathrm{X} 4$

$-6 B 1 \times 4$

$6 \mathrm{U1X} 4$

$6 \mathrm{R} 1 \mathrm{X4}$

$-6 \mathrm{D} 1 \mathrm{X} 4$

$6 \mathrm{~V} 1 \mathrm{X} 4$ Other Liabilities

$6 \mathrm{~S} 1 \mathrm{X} 4$

Other Long-Term Capital of Deposid Money Banks

69

Drawings on Loans Extended

$-5 \mathrm{C} 1 \mathrm{Y} 4$

$-5 \mathrm{C} 1 \mathrm{~W} 4$

71

72

73

(73)

74

75

76

\section{Other Long-Term Capital of Other Sectors}

77

78

79

80

81

82

83

Drawings on Loans

Repayment on Loans

$-8 \mathrm{C} 1 \times 4$

Other Assets

$-8 \mathrm{C} 1 \mathrm{~W} 4$

$-8 \mathrm{~K} 1 \mathrm{X} 4$

$8 \mathrm{~W} 1 \mathrm{X} 4$

$8 P 1 W 4$

8 P1Y4

$8 \times 1 \times 4$

\section{Other Short-Term Capital of Deposit Money Banks}

$$
89
$$

90

Assets

$-5 L 2 \times 4$

Liabilities (National Currency)

$5 \mathrm{U} 2 \mathrm{X} 4$

$5 \mathrm{~V} 2 \mathrm{X} 4$

$5 \times 2 \times 4$

92 Other Liabilities

Other Shoth-Term Capital of Other Sectors

93

Loans Exiended

$-8 \mathrm{C} 2 \times 4$

$-8 \mathrm{~K} 2 \times 4$

$8 \mathrm{~W} 2 \times 4$

Liabilities (Foreign Reserves)

$8 \mathrm{P} 2 \times 4$

Other Loans Received

$8 S 2 \times 4$ 